\title{
Surviving widowhood: life alone in rural Australia in the second half of the nineteenth century
}

\section{GLENDA STRACHAN AND LINDY HENDERSON*}

ABSTRACT. In the second half of the nineteenth century in the remote farming district of Dungog in the colony of New South Wales on the Australian continent, widows faced harsh economic realities. Using civil registration records, census data, newspaper reports, statistical returns, family histories and other sources, we have, where possible, reconstructed the lives of these widows, particularly those with dependent children. This paper discusses the range of survival strategies used. It presents statistical evidence from official records, and adds vignettes of the lives of a handful of widows whose strategies can be explored more completely using additional historical sources.

\section{INTRODUCTION}

Jimmy Middleton died at Log Paddock and was buried ... in the little old cemetery. She [his widow] conducted the funeral. ... She then lived in a hut at Log Paddock, on a little money in the bank, and did sewing and washing for single diggers. ${ }^{1}$

This fictional account of one widow's survival strategy probably typifies many in the rural districts of Australia in the nineteenth century. In preindustrial societies where production, consumption and social support were based around a household most commonly comprising a husband, wife, their children and perhaps other kin, the transition to widowhood carried with it many hazards. ${ }^{2}$

\footnotetext{
* Both of the Centre for Work, Organisation and Wellbeing, Griffith Business School, Griffith University, Australia.
} 
Research into the fate of widows and widowers has led to an increased understanding of the diverse ways in which these individuals and their families adjusted to their life situation, especially in Europe but also in Canada and the United States. ${ }^{3}$ In South Africa, the inventories of property, including household goods and farm implements, that were compiled at the time of the death of one spouse have been used to examine the fluctuating fortunes of families. ${ }^{4}$ In nineteenth-century Europe, widows' chances were shaped by their social status and by economic factors as well as by their position in law and custom. ${ }^{5}$ Some became heads of their own households, but living within the household of a son, daughter or other kin was the option for 40 per cent of the rural widows identified in an Austrian study and for a similar proportion of widows and widowers in Iceland. ${ }^{6}$ This was also a common pattern in England. ${ }^{7}$ Dribe, Lundh and Nystedt identified five alternative strategies that were available to widows and widowers in pre-industrial Sweden. ${ }^{8}$ Where they were relevant - that is when there was a farm or other asset to pass on - wills, retirement contracts and other legal devices offered widows some protection while at the same time protecting the longer-term interests of other family members. Poor and landless widows led much more precarious lives. ${ }^{9}$ Widows and widowers with young children seem to have found it easier, or perhaps more important, to remarry. ${ }^{10}$ In the New World, too, women left alone faced particular difficulties. ${ }^{11}$ For instance, a study of widows in Nova Scotia found many occupying a changed and in many cases reduced social and physical space within their former homes and communities. $^{12}$

For the nineteenth century, the details of women's lives in rural New South Wales (NSW), the oldest of the British colonies in Australia, are elusive. Few of the letters or diaries women wrote have survived; the work that they performed was most often assumed as part of domestic production and went undocumented, even in the nineteenth-century enthusiasm for collecting statistics; the ideal of 'separate spheres' that represented 'progress' for the colony and respectability for the middle class meant that even women's significant achievements in the commercial world or as farmers were undervalued or ignored. ${ }^{13}$ For those women whose husbands had died, social convention and official records seem to have conspired to render their achievements particularly difficult to uncover, even though a strong thread in nineteenth-century fiction deals with the woman alone in the bush, with her partner absent in search of seasonal work, dead or having abandoned her. ${ }^{14}$ To some extent the plight of widows who were extremely poor, who lacked family support or who were unable to support themselves or their dependent children, has been analysed using the records of the various charitable organizations of the 
time, but their activities were confined to the cities. ${ }^{15}$ Little attention has been paid to the situation of widows in rural areas. Using the available evidence, in this article we seek to illuminate some aspects of widows' lives in one rural area of New South Wales.

\section{METHODOLOGY AND SOURCES}

This article forms part of a larger study of one valley in rural New South Wales in the second half of the nineteenth century. The research has sought to tease out a detailed picture of the people and their economic and social relationships as they occupied the land and formed a community of European landholders. It explores the place of origin of immigrants, their marriage patterns, social mobility and fertility. Of particular interest are the working patterns of women, including paid employment and other cash contributions to the family income as well as the unpaid labour of women in the home, on the farm and otherwise, which contributed to the household and the district economy.

The study relies on a social reconstruction of the Dungog district, comprising the agricultural area of the Upper Williams Valley and the small town of Dungog. Social reconstruction is an expansion of the methodology of population reconstitution which has been used for several decades in Europe ${ }^{16}$ Centuries of data are not available for Australia so that population reconstitution along the lines of Wrigley and Schofield is not possible, but the technique of using the individual registration of demographic events to establish details of the life of a community is employable. The use of this demographic information begins the process of the recreation of the life histories of individuals and the economic, family and social relations between them. The use of a range of sources moves the project into the realm of 'social reconstruction' rather than population reconstitution. The key sources for the study are the civil registration records of births, marriages and deaths, which began in 1856, together with Anglican Church parish records. ${ }^{17}$ Our database contains and cross-references life events (marriage, the birth of children, death) and includes as much detail as possible from other sources.

The database contains civil registration records of approximately 4,000 births, 1,300 deaths and 600 marriages for the district from 1856 (the beginning of state registration) until 1905 (for births) and 1910 (for marriages and deaths). These records are supplemented by the Anglican parish registers (1854-1894), which include details of about half the local population. This has been supplemented by a variety of statistics published annually by the government, which included vital statistics and information about land use, agriculture, manufacturing and other 
economic activity. Censuses were held every ten years and provide details of population growth, although there is no way of identifying individuals or household composition. Once only, in 1885, a list of all landholdings in the colony was produced. ${ }^{18}$ The Dungog Chronicle was a weekly newspaper published from 1888 and it provides a glimpse of the commercial and social life of the town and district. Commercial directories list businesses and their owners over a fifty-year period. ${ }^{19}$ More insight into local conditions comes from the records of the Department of Public Instruction, which administered elementary schools. ${ }^{20} \mathrm{~A}$ few family memoirs and published obituaries provide some additional evidence.

It was unusual for the people of Dungog to leave a will. This is easily explained by the fact that few had very much to leave. Some tools, perhaps a few cattle or horses and essential household goods, would be all that most labourers' families possessed. Farms were leased on an annual or three-yearly basis, in contrast to the longer leases in many English and European farming districts. Where there was an estate, it was typical to see a surviving spouse taking a share of the estate along with her children. ${ }^{21}$ Only after 1880 were government duties imposed on deceased's estates in a consistent way. ${ }^{22}$

Much information that might have been helpful in this study was never recorded or has been lost. Rate books do not appear to exist, nor have tenancy, police or court records been preserved. Probate records are not generally available, and are of limited utility. Few women (or men) wrote letters or kept diaries - or these, too, have been lost. Such first-hand accounts of women's work as remain suffer from the usual bias of such documents in presenting the experience of the educated and articulate. ${ }^{23}$ So the lives of the majority of women - the poor, the illiterate or the simply exhausted - can only be examined through indirect evidence derived from slender sources.

When considering the data relating specifically to widows, these difficulties increase. Death certificates were kept meticulously, recording details of marriage and spouse but rarely whether the spouse was still alive. ${ }^{24}$ Nevertheless, the civil registration records (principally the death and marriage records) have been used to determine all the women we can recognize as widows in these records. There were 447 death certificates issued to males aged 15 years or older between 1856 and 1910 and these have been checked to identify those who predeceased their wives. ${ }^{25}$ Only a few women (23) are designated 'widow' in their death certification, although many women whom we know from other sources to have been widows were not recognized as such on their death certificate. Therefore three distinct groups can be isolated from the civil registration data and provide 74 cases for examination. These are not a sample, but are the 
totality of widows identified for the period 1856 to 1910 in the Dungog registration district according to the criteria below. These distinct groups are:

1 women who are identified as widows on their death certification (23 cases).

2 women whose husbands died, leaving them with a dependent child or children (younger than 15 years), especially including young women, still of childbearing age, who were widowed. (For this group, men were selected on the basis that they died aged 40 years or less, and were recorded as having been married.) Where possible, the deceased were matched on the database with the death of the wife and, where this occurred at a later date, the wives were identified as widows (26 cases). In a few cases of commonly occurring names, there remains some uncertainty, although the names and ages of an individual's children, which were routinely noted on the death certificate, renders this matching less speculative.

3 widows who remarried, using their marriage certificates to identify them ( 25 cases); for comparison, remarriage of widowers is considered briefly.

\section{LIFE ON THE FRONTIER}

In the first half of the nineteenth century, the economic development of the Australian colonies was dominated by pastoral expansion; the population and the workforce were predominantly male and a low value was placed on female labour. ${ }^{26}$ Beginning with a large surplus of males, the gender imbalance in the colony gradually decreased over the nineteenth century, especially with the impact of mass immigration after $1840 .{ }^{27}$ However, Ruzicka and Caldwell, in the most extensive demographic study of family formation, noted that until the 1880s the large excess of males in the Australian colonies rendered marriage 'probable for nearly all females and impossible for a substantial proportion of men. ${ }^{28}$ Conditions in the colonies, such as insecurity of employment and the scarcity of family settlement, especially in the remote pastoral regions, may explain why the proportion of the population ever marrying was 'lower than might have anticipated from the situation in England' ${ }^{29}$ In our study, censuses reveal that the proportion of females in the population varied little between 1861 and 1901, at 46-7 per cent, with that in the town of Dungog itself rising from 48 per cent to 50 per cent at the 1891 census. In the more remote reaches of the valley, females represented 43 per cent of the population. ${ }^{30}$ 
The district that is the focus of this study was chosen because it typifies the pattern of settlement in the fertile coastal fringe of the colony of NSW in the second half of the nineteenth century. Called the 'wet frontier' by one writer in order to distinguish it from the dry inland pastoral country, here isolation could be measured in terms of dangerous river crossings, frequent floods, treacherous harbours and coasts rather than in sheer distance. $^{31}$ The site of the study is one census/civil registration district comprising the valley along the Upper Williams River and the growing town of Dungog which became the commercial centre for the district. It has not experienced the development of any large-scale mining or industry and has not become absorbed as a suburb or satellite town of the larger city of Newcastle and so it remains a discrete valley. In many ways its boundaries, particularly in the upper reaches of the valley, were very real to the inhabitants. In addition, the civil registration records and the Anglican parish records are available for this district.

As early as the 1820s, large grants of land were made to a handful of free settlers and these formed the base from which European settlement expanded. Thus, a small number of families owned large estates of several thousand acres, while the district mostly comprised small and medium holdings leased from the large estates or purchased freehold or conditionally under the land reform acts of the early 1860s (Crown Lands Alienation Act (New South Wales), 1861; New South Wales Crown Lands Occupation Act (New South Wales), 1861). This land reform enabled the large estates to be broken up but more importantly it resulted in the alienation of land previously unoccupied by Europeans. Many of these newer settlers were assisted immigrants who brought with them experience of farm work, but little money.

In the more steeply sloping parts of the Upper Williams and its tributaries - further from the township, where land was progressively made available for conditional purchase from 1861 - the soil was less fertile, the land more heavily timbered and the river flats narrow. The more extensive river flats closer to the town enabled tenant farmers to grow crops, chiefly maize. We have no records of tenancy agreements but a short period of from one to three years seems to have been the norm. ${ }^{32}$ Most farms, whether owned or leased, relied on family labour supplemented from time to time by hired labour. Mechanization was slow to arrive in the Upper Williams Valley, and much of the work on the farms was carried on by the most primitive methods. ${ }^{33}$ Dairying became a significant industry in the 1890s. Small farmers and labourers alike carried on any number of tasks related to clearing and fencing the land, raising cattle and growing crops. Reay has pointed out the diverse skills which were expected of a farm labourer in Kent; the Dungog farm worker, whether 
proprietor, share farmer or labourer, would have needed a similar armoury of talents, while his wife's contribution was most often made in the dairy, henhouse, vegetable garden and house, although there is evidence of intermittent waged labour for all family members including women and children. ${ }^{34}$

The population of the town and district grew from approximately 1,500 European inhabitants in 1850 to over 4,000 in 1900 . By the 1850 s, very few of the original inhabitants, members of the Gringai people, remained. Civil registration and Anglican parish records reveal a population that came from varied places in Britain but, once settled in the valley, they tended to stay. Marriage records reveal little social mobility, with most marriages taking place between members of the local community. ${ }^{35}$ Husbands and wives generally worked together at a joint enterprise that ensured survival for the household in a way more reminiscent of a preindustrial pattern of family labour than the form that had become the standard in Western Europe and America and in the major towns of Australia in the late nineteenth century. A mixture of work for the household or family holding, work for wages and the informal exchange of labour and goods between neighbours or kin was the mainstay of most households.

Farm work was shared by men, women and children but the work of the last two groups rarely appears in public records: the agricultural section of the Statistical Register focussed on production for export and not on production for household use or local markets (for instance, butter, eggs, poultry and vegetables). In 1885, 67 per cent of the land was owned by 24 individuals and the remainder was held by 295 others. There were an estimated 300 people who rented land from private landowners. ${ }^{36}$

\section{WIDOWHOOD}

The colony and district were dangerous places, especially for men. One nineteenth-century academic, mathematician and commentator noted that accidental deaths per annum per 1,000 of the population above the age of 10 were 2.01 for males and 0.46 for females for the period 1869-1875, compared to 0.99 and 0.23 in England. ${ }^{37}$ In the Dungog registration district, more than 10 per cent of the male population died as the result of accidents, with drowning and accidents involving horses the most common causes. ${ }^{38}$ Death from illness could also be sudden, with diseases such as typhoid killing within days or weeks, while some survivors lingered as invalids.

Of the 448 adult males whose death certificates are available, just over half (280) were over fifty years of age. Nineteen per cent (84) left children 


\section{TABLE 1}

Men who died aged 40 years or younger and their widows who had children, identified through registration of deaths, Dungog District, New South Wales, 1859-1910

\begin{tabular}{|c|c|c|c|c|}
\hline $\begin{array}{l}\text { Year of } \\
\text { death }\end{array}$ & $\begin{array}{l}\text { Age at } \\
\text { death }\end{array}$ & Husband (deceased) & Wife & $\begin{array}{l}\text { Number of } \\
\text { children }\end{array}$ \\
\hline 1859 & 39 & $\begin{array}{l}\text { Henry: farmer } \\
\text { Age at marriage: } 24\end{array}$ & Esther & 5 \\
\hline 1859 & 38 & $\begin{array}{l}\text { John: farmer } \\
\text { Age at marriage: } 32\end{array}$ & Esther & $\begin{array}{l}3\left(6 \& 3 \frac{1}{2} \text { years }\right. \\
19 \text { months })\end{array}$ \\
\hline 1862 & 31 & $\begin{array}{l}\text { Thomas: farmer } \\
\text { Age at marriage: unknown }\end{array}$ & Mary & $4\left(7,6,5 \& 3 \frac{1}{2}\right.$ years $)$ \\
\hline 1863 & 21 & $\begin{array}{l}\text { Charles: farmer } \\
\text { Age at marriage: } 19\end{array}$ & Catherine & 1 ( $1 \frac{1}{2}$ years) \\
\hline 1864 & 25 & $\begin{array}{l}\text { Joseph: farmer } \\
\text { Age at marriage: } 20\end{array}$ & Ann & $\begin{array}{l}2 \text { ( } 1 \frac{1}{2} \text { years } \& \\
6 \text { months })\end{array}$ \\
\hline 1864 & 40 & $\begin{array}{l}\text { Henry: farmer } \\
\text { Age at marriage: } 21\end{array}$ & Mary & 7 \\
\hline 1866 & 40 & $\begin{array}{l}\text { George: farmer } \\
\text { Age at marriage: } 29\end{array}$ & Mary Ann & $3(9,7 \& 5$ years $)$ \\
\hline 1870 & 36 & $\begin{array}{l}\text { George: baker } \\
\text { Age at marriage: } 28\end{array}$ & Harriet & $\begin{array}{l}4 \text { ( } 7,6 \text { \& } 3 \text { years; } \\
4 \text { months) }\end{array}$ \\
\hline 1875 & 25 & $\begin{array}{l}\text { Peter: labourer } \\
\text { Age at marriage: } 22\end{array}$ & Rossina & 1 ( 2 years $)$ \\
\hline 1875 & 39 & $\begin{array}{l}\text { James: surgeon } \\
\text { Age at marriage: } 28\end{array}$ & Georgina & 1 \\
\hline 1877 & 39 & $\begin{array}{l}\text { John: wheelwright } \\
\text { Age at marriage: } 21\end{array}$ & Sarah (?) & $\begin{array}{l}5(15,13,9 \& 4 \text { years; } \\
3 \text { months })\end{array}$ \\
\hline 1880 & 33 & $\begin{array}{l}\text { John: farmer } \\
\text { Age at marriage: } 30\end{array}$ & Mary Jane & 2 \\
\hline 1881 & 34 & $\begin{array}{l}\text { Alfred: farmer } \\
\text { Age at marriage: } 25\end{array}$ & Margaret & $\begin{array}{l}4(5,4 \& 2 \text { years } \\
7 \text { months) }\end{array}$ \\
\hline 1883 & 26 & $\begin{array}{l}\text { David: clerk } \\
\text { Age at marriage: } 21\end{array}$ & Elizabeth & $1\left(3 \frac{1}{2}\right.$ years $)$ \\
\hline 1887 & 40 & $\begin{array}{l}\text { Charles: carpenter } \\
\text { Age at marriage: } 30\end{array}$ & Elizabeth & 9 \\
\hline 1888 & 27 & $\begin{array}{l}\text { Charles: farmer } \\
\text { Age at marriage: } 23\end{array}$ & Louisa & 2 ( $3 \& 1$ years) \\
\hline 1892 & 32 & $\begin{array}{l}\text { Joseph: labourer } \\
\text { Age at marriage: } 28\end{array}$ & Sarah & 1 (2 years) \\
\hline 1896 & 31 & $\begin{array}{l}\text { Thomas: labourer } \\
\text { Age at marriage: } 21\end{array}$ & Elizabeth & $4(10,8,6 \& 3$ years $)$ \\
\hline 1896 & 33 & $\begin{array}{l}\text { Frederick: carrier } \\
\text { Age at marriage: } 21\end{array}$ & Mary Ann & $\begin{array}{l}6(10,8,7,5 \text { \& } 2 \text { years } \\
5 \text { months })\end{array}$ \\
\hline 1897 & 29 & $\begin{array}{l}\text { James: labourer } \\
\text { Age at marriage: } 20\end{array}$ & Mary Agnes & $3(6,4 \& 3$ years $)$ \\
\hline
\end{tabular}


TABLe 1 (Cont.)

\begin{tabular}{|c|c|c|c|c|}
\hline $\begin{array}{l}\text { Year of } \\
\text { death }\end{array}$ & $\begin{array}{l}\text { Age at } \\
\text { death }\end{array}$ & Husband (deceased) & Wife & $\begin{array}{l}\text { Number of } \\
\text { children }\end{array}$ \\
\hline 1897 & 40 & $\begin{array}{l}\text { Robert } \\
\text { Age at marriage: } 19\end{array}$ & Betsy & $\begin{array}{r}8(21,19,17,14,11,8 \\
\& 3 \text { years; } 3 \text { months })\end{array}$ \\
\hline 1901 & 40 & $\begin{array}{l}\text { James } \\
\text { Age at marriage: } 39\end{array}$ & Alice & 1 (1 week) \\
\hline 1905 & 37 & $\begin{array}{l}\text { William: labourer } \\
\text { Age at marriage: } 34\end{array}$ & Alice Ada & 1 (1 year) \\
\hline 1905 & 38 & $\begin{array}{l}\text { William: farmer } \\
\text { Age at marriage: unknown }\end{array}$ & Alice & $3(6,4 \& 1$ years $)$ \\
\hline 1910 & 26 & $\begin{array}{l}\text { Percy: farmer } \\
\text { Age at marriage: } 22\end{array}$ & Ethel & $\begin{array}{l}2 \text { (9 months; } \\
1 \text { possibly deceased })\end{array}$ \\
\hline 1910 & 40 & $\begin{array}{l}\text { Patrick: telegraph line repairer } \\
\text { Age at marriage: } 27\end{array}$ & Bridget & $\begin{array}{l}8(14,10,8,6 \& 2 \\
\text { years; } 5 \text { months; } 2 \\
\text { possibly deceased })\end{array}$ \\
\hline
\end{tabular}

${ }^{a}$ Details of the husband's occupation, his age at marriage and the ages of the children at his death are given where these are included on the death certificate. Surnames are not given out of considerations of confidentiality, here and throughout this article.

Source: New South Wales Civil Registrations of Deaths, Dungog District, 1856-1910, now in the New South Wales Registry of Births, Deaths and Marriages, Regent Street, Chippendale, New South Wales.

aged 15 years or younger. Over a quarter (28 per cent) left only one child, 60 per cent left between two and five children, and eleven men had six, seven or eight dependent children at the time of their death. Among the men aged over fifty, there were several who had grown children along with younger ones, and of course there were some whose responsibility as parents was effectively complete. It is the widows who found themselves without a husband but with the responsibility of care for dependent children that are the main concern of this study. Age alone did not determine family status in our study. Among those identified as dying as a result of an accident, for example, was a 58-year-old surgeon who had four children of 13 years old or younger, including an infant, and a 48-year-old farmer, whose three children included a 4-year-old, a 3-year-old and an infant. Other older men, typically the fathers of large families, left behind them wives and numerous children, some of whom were very young. ${ }^{39}$

However, the present study focuses on the 35 married men who died aged 40 or younger. One of these was a widower (his wife dying a few months prior to his own death) and in one other case the whole family was swept away in their hut during a flood. A further seven had no children listed on their death certificates. The remaining 26 are outlined in Table 1. 
As expected, the youngest of these men had been married three to five years and left a widow and one or two children, while some at the older end of the range had many more: among the 39- and 40-yearolds five, seven and eight children survived their father. These were a mixture of grown children and little ones: as an example, Robert (40 years old) had at least three, possibly four, children capable of earning a living, including one married daughter aged 21, but Betsy, his widow, still had four younger children to care for and the youngest was a baby three months old; in 1896 Mary Ann, widow of a 38-year-old carrier, was left with six children, the oldest being 10 years old. The deceased's occupation was not always recorded on the death certificate, but there are 12 farmers, 5 labourers, a baker, a carpenter, a wheelwright, a clerk and a carrier among them and, perhaps a sign of modern times, a telegraph linesman. This presents a similar profile to that of the community as a whole.

We might expect that experiences of widowhood would have varied and depended on the widow's age, the presence of dependent children or grown children, the availability of relatives or others to provide material and emotional support, and the socio-economic position of the widow and others in her kinship network, if any. Dribe, Lundh and Nystedt identified five alternative strategies that were available to widows and widowers in pre-industrial Sweden:

1 carrying on alone as head of household,

2 remarrying,

3 entering a household headed by a child or spouse of a child,

4 entering a household headed by someone other than a child, and

5 migrating out of the parish. ${ }^{40}$

Similar alternatives were available to widows and widowers in the Dungog area in the nineteenth century and it would be expected that widows might have employed more than one strategy at various times.

\section{IV.1 Widows who carried on alone as head of household}

There is evidence that some women carried on leading the family business. In 1886, when the only official record of individual landholders was made, 14 women (4 per cent of landholders) were identified as holding land in their own names. ${ }^{41}$ Further details of 4 of these women have been obtained using the Anglican parish registers and all were widows with adult children. Three held between 28 and 36 acres and possessed enough livestock for a limited cash income but these properties would not have 
been economically viable. A glimpse at the diversified nature of farm life comes from one of these: the woman's husband, who died in 1883, gave his occupation as carrier and her daughter was a domestic servant. Women such as this widow would have played a vital part not only in household production but also in earning a cash income, even during their husband's life. The farm would have provided some income but not sufficient to sustain a family, a situation not uncommon in the district. In contrast, the farm of 560 acres was a desirable holding and one of the sons, aged 26, was living there in 1886 when he married a grazier's daughter. (The term 'grazier' was used to describe a successful landholder.)

A commercial directory produced in 1900 offers the possibility of comparing landholders with those recorded in $1886 .{ }^{42}$ Twelve women were included in Yewen's directory from a total of 296 farms and some residential landholders in Dungog, and using marriage, birth and death records three farms can be identified as falling into the hands of widows. In 1888 Mary Anne, aged 52, was widowed with six children aged 9 to 28 years. In 1899, she was growing wheat and potatoes, and had dairy and beef cattle on 145 acres at Bendolba, a hamlet in the Upper Williams Valley. Her son John had maize and wheat fields and a dairy herd, also at Bendolba. ${ }^{43}$ She died in 1910 aged 72 and her occupation was described as 'domestic duties'. ${ }^{44}$ At Main Creek, Ann, who was widowed in 1891, had presumably taken over control from her late husband because she was growing wheat and maize in addition to having dairy and beef cattle. Her son Samuel lived in the same area growing maize and grazing cattle. This family was well placed, with 466 acres, 11 horses and 130 cattle in 1885 . Meanwhile at Pine Brush, Bridget, widowed in 1892 with six surviving children aged 3 to 18 , had a dairy and grazed cattle. In 1885 the farm was recorded as 283 acres with 150 cattle and 20 horses, putting the family in the category of the well-to-do farmers of the district. Like the other two farming widows she had family close to her: her brothers-in-law were farmers, orchard-keepers and dairy farmers and grazed cattle nearby. Birth registrations show the long residence of these women in the colony, with children born in and around the Dungog district. ${ }^{45}$ All these families had sufficient landholdings to be successful farmers, enjoying a reasonably high standard of living, and the widows almost certainly remained on the same holding they had occupied prior to the death of their husband, and most importantly in close proximity to kin. The designation 'head of household' has no particular relevance in the Australian context, as it does in some European countries. ${ }^{46}$ Knowing that individuals lived with or near kin does not give us much idea of the power relationships that might have existed within the kinship network, but there is no doubt that 
the co-location of networks of closely related adults provided important support mechanisms. Widows were also able to protect their own interests and probably those of their minor children by remaining on the family farm.

In the town of Dungog other widows continued in a familiar role, perhaps assuming new responsibilities as sole proprietor of a family business. Three stand out. Jane outlived her husband by only two years, during which she took over his role as licensee of the hotel they had operated together. ${ }^{47}$ Her death certificate identifies her as a hotelkeeper. Similarly, Eliza was an experienced businesswoman prior to widowhood. In 1851, 1861, 1868, and from 1874 to 1880, Eliza's name was listed in various almanacs as a store keeper in the town of Dungog. She was in her early forties, and already the breadwinner when her husband died in 1872 after a long illness. ${ }^{48}$ By 1884 Eliza's name had disappeared from the almanacs and was replaced by that of Henry, her son. ${ }^{49}$ Eliza had managed the store for ten years or so and eventually handed the reins of her business to her youngest surviving son, Henry. ${ }^{50}$ When she died in 1896 aged 71, the Dungog Chronicle printed a long obituary, in which it described her late husband as a storekeeper yet made no mention of her working life. ${ }^{51}$ At Booral, a tiny hamlet some twenty kilometres from Dungog, Eliza Jane was already well known for her boarding house when she obtained a colonial wine license in $1896 .{ }^{52}$ She was at that time aged about 53, recently widowed and the mother of seven, the youngest 16 years old. ${ }^{53}$ Her husband had owned a timber mill, but after his death Eliza Jane established what would have been the colonial equivalent of a coaching inn where she had previously taken in boarders (perhaps mill workers).

Because an occupation was rarely given for women on the death certificates, it is impossible to know how many individuals were able to survive widowhood by taking jobs as domestic servants or by starting or expanding small-scale business enterprises such as raising poultry or sewing. For example, women who regularly acted as midwives were rarely listed as having an occupation on their death certificate. $^{54}$

\section{IV.2 Widows who remarried}

Marriage certificates identify widows who remarried. Altogether, 25 widows are recorded as marrying between 1856 and 1890 but, interestingly, none in the more populous and arguably more prosperous $1890 \mathrm{~s}^{55}$ However, the extent of remarriage is unclear because the available records do not identify those widows who left the district in order to marry. 
Occupations appear more regularly for widows than for single women on marriage certificates and widows are frequently, though not always, recognized as having an occupation of their own-be it nurse, storekeeper, housekeeper, domestic servant - or as having a private income ('private life' given as occupation), while single young women were most often listed as 'living with parents' or simply 'spinster'. 'Private life' may be an acknowledgement of the widow having provided for herself and any children, or of her perceived and/or real independence. It is clear from the records that widows without dependent children or with an income had greater chances of remarrying in the district. ${ }^{\mathbf{5 6}}$

Fourteen of these women married widowers, the majority of whom (12) were farmers with the remaining 2 in trades. Information about children is recorded in three cases: when Elizabeth, a general servant, married the farmer Samuel in 1856, neither had children. In contrast, Martha married William in 1871 when she was 50 and had eight children; he was 55 and had no living children but all Martha's children were independent or nearly so. Other marriages such as that of Jane (with 5 living children) and Joseph (with 11) formed combined families. In another case, both the parties were older and we know from additional sources that when 58year-old Sarah, a nurse, married 69-year-old Samuel, both had grown children. ${ }^{57}$

Widows who married single men usually had an occupation or income. Five of these 11 women recorded an occupation on the marriage certificate: Mary and Bridget were storekeepers; Anne was a housekeeper; Sarah was a servant; and Emma, aged 27, recorded 'private life' as the occupation. Mary, aged 23 and with no children, was recorded as 'living with parents'. It is likely that a number of the women had no children. Others had some income or occupation to offer and this seems to have made them better prospects for marriage and given them the option of marrying a single man. From the early 1880 s widows were more likely to marry single men and this may reflect the increased population of the district.

Twelve of the men who married widows were farmers (the most common occupation in the registers) and four others had occupations or trades (blacksmith, brick maker, shoemaker), leaving three designated as labourers and five with no recorded occupation. Children from previous marriages are generally but not uniformly entered in the registers, although it appears that many of the individuals were childless at the time of marriage. By searching the online historical index of births, deaths and marriages, a few more details of the subsequent lives of these widows is revealed. It is not always possible to identify them with certainty, but at least eight of the widows who remarried bore children to their new husband. It would seem that the first of these children was most 
often born in the same calendar year as the wedding and some of these unions went on to produce three, four or five children. ${ }^{58}$ For these widows who remarried, life appears to have followed a trajectory not dissimilar to that of their non-widowed sisters in similar socio-economic circumstances.

Twelve widowers' marriages are recorded in the Anglican parish registers during the same period, in nine instances to women who had not previously been married. Some higher-status men married much younger women, for instance the 41-year-old bank manager married a single woman aged 20, a miller aged 42 married an 18-year-old, and the bride of a clerk of Petty Sessions was ten years his junior. However, marriages between individuals who were similar in age and occupational level were more frequent, just as in the district as a whole. ${ }^{59}$

Evidence that some widows formed new relationships without remarrying comes indirectly from the birth registrations. Six widows bore children who were clearly conceived after the death of the husband. On one we have no further information in any records, so she appears to have been a stranger in town and may even have called herself a widow rather than identifying herself as unmarried at the time of giving birth. In four further cases, a single child was born a few years after the husband's death (or two children in one instance), when the woman was nearing the end of her childbearing days (over the age of 38). For example, the widow (aged 38) of an unqualified medical doctor, who was left with several young children and worked as a midwife from time to time, bore a child some years after her husband died. One further widow was 27 years old and had one child two years and seven months after the death of her husband. Based on evidence on the death certificates - including comments on the poverty of the family, the death of the widow from consumption or a child dying from neglect - three of these six widows would seem to have been poor and illiterate. The details of the domestic arrangements of such women remain unknown, although we may speculate that at least one widow established an ongoing relationship with the father of her child, since his name was added to the birth certificate at a much later date. Among the poor of the district, a common law marriage may have been acceptable.

\section{IV.3 Widows who migrated out of the parish}

Moving away from the district was likely to be a strategy used by women who were without means or employment or whose relations were elsewhere. These women remain lost as far as the current study is concerned. We do not know whether they found new partners and new 
opportunities, or ended up poverty-stricken and dependent on public or private charity.

\section{IV.4 Women who entered another household}

One characteristic of the settlement process in the farming district of Dungog was the frequency with which kin settled in close proximity to each other and co-operated in farm work and in domestic production. The registration of births included details of those who witnessed or assisted at the birth. Poverty, isolation (distance from the town and/or difficult travelling conditions) or personal preference meant that many women were attended by a family member, usually her mother or mother-in-law, whose name appears on the birth certificate as nurse or witness, reflecting the importance of family ties and the availability of help from family members. ${ }^{60}$

We would therefore expect to see many widows remaining in their previous home or those of close kin (usually an adult son or daughter) and this seems to have been the strategy most widows adopted. Family histories and memoirs support this supposition. For example, Elizabeth arrived in the colony in 1839 with her husband John and children. John was employed at various times as a farm hand then as an overseer, and he was for a time a tenant farmer. He died in 1873 at the age of 62 and Elizabeth survived him by 20 years, dying at the age of 83 . For two decades she lived with her youngest son and his wife. She contributed to the family economy as best she could: 'She did odd jobs like feeding calves and droving cattle into a fresh paddock of feed, or anything else she could think of that she could manage. ${ }^{\mathbf{6} 1}$

\section{IV.5 Widows in poverty}

A town and district of the size of Dungog had no organized system of poor relief. A widow had usually to fall upon her own resources or those of her family or her husband's family to survive. Until the introduction of an old age pension in 1900, any individual, widowed or not, who could not earn enough to get by would have been in a similar situation. ${ }^{62}$ Life was especially precarious for the widows of labourers, who were landless and had worked mostly as farm labourers or general labourers, eking out a living taking casual or seasonal work. ${ }^{63}$ Significantly more labourers that farmers or skilled workers died under the age of 40 and fewer lived into old age. A lack of social mobility in the community meant that it was exceptional for individuals to move from one occupational category to 
another ${ }^{64}$ Widows without the ability to earn their own living or without grown children or other relatives to help out were the most vulnerable women in the community, and are the most difficult to identify or trace. Although assistance for women and children was offered by various Christian denominations, and widows and their children were leading recipients of private and public philanthropy, organized poor relief was confined to the cities. ${ }^{65}$

The local community was not oblivious to the needs of its poorest members or of those who had suddenly fallen upon hard times. As an example, the local newspaper reported that a ball was held in aid of the widow and children of Thomas R., who had died in a mining accident, and it was declared a grand success as $£ 9 / 10$ was raised. This occasion demonstrated the close co-operation in the community: it was organised by a local dancing club, and various local musicians volunteered their services. ${ }^{66}$ The widow remarried two years later. ${ }^{67}$

\section{IV.6 Older widows}

The survival strategies used by older widows are difficult to uncover, though a little information can be gained through death certificates. It was unusual for widowhood to be recorded in the civil registration of death; nevertheless 27 women were thus identified. They ranged in age from 38 to 94 at the time of their death. Two had been widowed twice, one dying at the age of 88 and the other at 94 . The period of widowhood can only be determined for 17 of the 27 (using the husband's death certificate), and this ranges from 1 to 24 years (see Table 2). Eight were widowed for less than 10 years at the time of their death. Of the 17 women, 5 were in their 70 s when their husband died, 6 were in their 60 s and 3 were aged 55-59. The others were aged 52, 49 and 35, lending support to the suggestion that younger widows were more likely to remarry. We can gain some further information about these last three widows from the death certificates. Elizabeth died aged 38 in 1859 of lingering consumption, which had lasted for two years. She had borne eight children, four girls and four boys, and her farmer husband George had died of consumption three years earlier. Catherine was aged 49 when she was widowed in 1873 and she outlived her husband, a farmer, by 24 years. At his death, she had seven living children aged 10 to 27. Ann, given the occupation of schoolmistress on her death certificate, was 50 years old when she died in 1859, leaving one child. She was born on the Isle of Wight and her death was notified by her nearest neighbour, but no further details about this widow can be gleaned. Jane Ann was the second wife of her publican husband and about 19 years his junior. They had no children, although her husband had two 
TABLE 2

Widows who did not remarry in Dungog District, New South Wales, 1859-1908, identified through registration of deaths

\begin{tabular}{|c|c|c|c|c|c|}
\hline $\begin{array}{l}\text { Year of } \\
\text { death }\end{array}$ & Name & $\begin{array}{l}\text { Widowhood } \\
\text { (duration) }\end{array}$ & $\begin{array}{l}\text { Age at } \\
\text { widowhood }\end{array}$ & $\begin{array}{l}\text { Occupation } \\
\text { of wife; } \\
\text { husband }\end{array}$ & $\begin{array}{c}\text { Details of children } \\
\text { at time of } \\
\text { husband's death }\end{array}$ \\
\hline 1859 & Ann & Unknown & (died at 50) & $\begin{array}{l}\text { Schoolmistress; } \\
\text { unknown }\end{array}$ & 1 son \\
\hline 1859 & Elizabeth & 3 years & 35 & Widow; farmer & 4 daughters \& 4 sons \\
\hline 1886 & Catherine & 12 years & 59 & $\begin{array}{l}\text { No information; } \\
\text { farmer }\end{array}$ & $\begin{array}{l}2 \text { daughters } \& 2 \text { sons } \\
\text { Aged } 17 \text { to } 24 \text { years }\end{array}$ \\
\hline 1892 & Mary Ann & 15 years & 61 & Widow; farmer & No children listed \\
\hline 1892 & Elizabeth & 10 years & 77 & Widow; farmer & $\begin{array}{l}7 \text { daughters and } 1 \text { son } \\
\text { Aged } 31 \text { to } 52 \text { years }\end{array}$ \\
\hline 1897 & Catherine & 24 years & 49 & Widow; farmer & $\begin{array}{l}5 \text { daughters \& } 2 \text { sons } \\
\text { Aged } 10 \text { to } 27 \text { years }\end{array}$ \\
\hline 1898 & Mary Ann & 20 years & 58 & Widow; farmer & 3 daughters \& 5 sons \\
\hline 1899 & Grace & 8 years & 64 & Widow; farmer & $\begin{array}{l}5 \text { daughters } \& 1 \text { son } \\
\text { Aged } 28 \text { to } 42 \text { years }\end{array}$ \\
\hline 1900 & Georgina & 4 years & 70 & Widow; farmer & $\begin{array}{l}2 \text { daughters \& } 7 \text { sons } \\
\text { Aged } 25 \text { to } 51 \text { years }\end{array}$ \\
\hline 1901 & Eleanor & 11 years & 70 & Widow; farmer & $\begin{array}{l}2 \text { daughters } \& 6 \text { sons } \\
\text { Aged } 26 \text { to } 38 \text { years }\end{array}$ \\
\hline 1902 & Catherine & 6 years & 71 & $\begin{array}{l}\text { Widow; ladies' } \\
\text { dressmaker }\end{array}$ & $\begin{array}{l}3 \text { daughters } \& 2 \text { sons } \\
\text { Aged } 39 \text { to } 48 \text { years }\end{array}$ \\
\hline 1904 & Ann & 8 years & 56 & Widow; farmer & $\begin{array}{l}2 \text { daughters \& } 6 \text { sons } \\
\text { Aged } 13 \text { to } 28 \text { years }\end{array}$ \\
\hline 1904 & Elizabeth & 7 years & 65 & Widow; farmer & $\begin{array}{l}2 \text { daughters \& } 4 \text { sons } \\
\text { Aged } 24 \text { to } 38 \text { years }\end{array}$ \\
\hline 1905 & Mary Jane & 10 years & 62 & Widow; grazier & $\begin{array}{l}3 \text { daughters \& } 5 \text { sons } \\
\text { Aged } 20 \text { to } 41 \text { years }\end{array}$ \\
\hline 1905 & Jane Ann & 2 years & 52 & $\begin{array}{l}\text { Hotel keeper; } \\
\text { publican }\end{array}$ & no children \\
\hline 1905 & Ellen & 13 years & 65 & $\begin{array}{l}\text { Storekeeper; } \\
\text { storekeeper }\end{array}$ & $\begin{array}{l}1 \text { daughter \& } 1 \text { son } \\
\text { Aged } 30 \& 34 \text { years }\end{array}$ \\
\hline 1908 & Elizabeth & 19 years & 60 & Widow; labourer & $\begin{array}{l}6 \text { daughters \& } 4 \text { sons } \\
\text { Aged } 15 \text { to } 41 \text { years }\end{array}$ \\
\hline 1908 & Mary Ann & 1 year & 75 & Widow; grazier & $\begin{array}{l}1 \text { daughter \& } 4 \text { sons } \\
\text { Aged } 30 \text { to } 40 \text { years }\end{array}$ \\
\hline
\end{tabular}

Source: As in Table 1.

grown children from his first marriage. The only other widow for whom an occupation is given is that of Ellen. Both she and her husband are designated 'storekeeper' on their death certificates. James died aged 75 
in 1892 and Ellen in 1905, aged 78. At the time of James's death Ellen had two adult children. All the other husbands were farmers or graziers, save one who was a labourer and one a ladies' dressmaker. Most of the widows had extensive families of adult children, many living in the district. While direct evidence of co-habitation with family members is difficult to find, these details reinforce the idea that widows frequently lived with or nearby their adult children or other relations.

\section{CONCLUSION}

This study has provided only a few clues as to the strategies widows employed or their effectiveness in ensuring their own and their family's survival. The few records which are accessible provide as many tantalizing clues as they do certain facts. What we have seen is that widows used a variety of strategies in order to survive and to protect their interests and those of their children. What widows did depended on the options that were available to them and these were dictated by social, economic and gender-specific factors. That most families were immigrants or the Australian-born children of immigrants makes for an assumption that the pattern of residency and household composition would generally follow that of their English, Irish and Scottish antecedents. ${ }^{68}$ Such property (real and otherwise) as they had was distributed without recourse to legal devices. ${ }^{69}$

A pattern appears to emerge where widows remained in their own household or that of an adult child. Some became dependent on adult children or on community support (at least for a time) while others took over the reins of the family enterprise, working on their own account and preparing the way for their children to succeed them. Age at widowhood and the age of a widow's children undoubtedly influenced the choices that she made or the fate that was thrust upon her. Remarriage was possible, but it appears that this was unlikely for widows with children and without their own income or means, at least in this district. Women with land or who were engaged in sound commercial enterprises were clearly in a more advantageous situation than the poor and landless. Again and again, this latter group eludes the grasp of the researcher, as do those who migrated.

Women who were alone survived by making alliances or marriages where they could; they made the most of their independence by continuing in an occupation for which they were already equipped, or they made do with whatever work would provide some income. This included dressmaking, shopkeeping, working as a domestic servant, nurse, midwife or housekeeper. Many were absorbed into the family or household 
enterprise. Perhaps some were forced to leave the district to seek employment or charity in the larger centres of population: about these we can only speculate.

\section{ACKNOWLEDGEMENTS}

This research was supported by an Australian Research Council Large Grant. We acknowledge the research assistance of S. D. Owen.

\section{END NOTES}

1 Henry Lawson, 'The golden graveyard', in Lloyd O'Neil ed., Joe Wilson's mates (Victoria, 1970; first published Sydney, 1904), 93-4.

2 Martin Dribe, Christer Lundh and Paul Nystedt, 'Widowhood strategies in preindustrial society', Journal of Interdisciplinary History 38, 2 (2007), 207-32.

3 Ida Blom, 'The history of widowhood: a bibliographic overview', Journal of Family History 16, 2 (1991), 191-8.

4 Laura J. Mitchell, " "This is the mark of the widow": domesticity and frontier conquest in colonial South Africa,' Frontiers 28 (2007), 47-76.

5 Beatrice Moring, 'Widowhood options and strategies in pre-industrial northern Europe: socio-economic differences in household position of the widowed in 18th and 19th century Finland', History of the Family 7, 1 (2002), 79-99.

6 Jim Brown, 'Becoming widowed: rural widows in lower Austria, 1788-1848', History of the Family 7, 1 (2002), 117-24; G. Gunnlaugsson and L. Guttormsson, 'Transition into old age: poverty and retirement possibilities in late eighteenth and nineteenth century Iceland', in John Henderson and Richard Wall eds., Poor women and children in the European past (London, 1994).

7 Richard Wall, 'Elderly widows and widowers and their co-residents in late nineteenthand early twentieth-century England and Wales', History of the Family 7, 1 (2002), $139-55$

8 Dribe, Lundh and Nystedt, 'Widowhood strategies', 207-32.

9 Moring, 'Widowhood options', 97.

10 Kevin McQuillan, 'Family composition and remarriage in Alsace, 1750-1850', Journal of Interdisciplinary History 33, 4 (2003), 547-67.

11 Bettina Bradbury, 'Surviving as a widow in nineteenth-century Montreal,' Urban History Review 17, 3 (1989), 148-60.

12 Katie Pickles, 'Locating widows in mid-nineteenth century Pictou County, Nova Scotia', Journal of Historical Geography 30, 1 (2004), 70-86.

13 Glenda Strachan and Lindy Henderson, 'Lost labourers: the difficulties of uncovering the lives of farm women, 1850-1900', in B. Bowden and J. Kellett eds., Transforming labour: proceedings of the eighth National Labour History Conference, University of Sydney 30 June - 2 July, Australian Society for the Study of Labour History and Business and the Labour History Group (Sydney, 2003), 362-70.

14 For example, Barbara Baynton, 'The chosen vessel', in her Bush Studies (Sydney, 1902); Henry Lawson, 'The drover's wife', in his Short stories in prose and verse (Sydney, 1894) (both available on Gutenberg.net.au).

15 Stephen Garton, Out of luck: poor Australians and social welfare 1788-1988 (Sydney, 1990). 
16 See E. A. Wrigley and R. S. Schofield, The population history of England 1541-1871 (Cambridge, 1981), and E. A. Wrigley, R. S. Davies, J. E. Oeppen and R. S. Schofield, English population history from family reconstitution 1580-1837 (Cambridge, 1997).

17 New South Wales Registry of Births, Deaths and Marriages, Attorney-General's Department of New South Wales, Civil Registration Certificates, records now held at the New South Wales Registry of Births, Deaths and Marriages, Regent Street, Chippendale, New South Wales; Anglican Diocese of Newcastle Parish Registers, available on microform at the Auchmuty Library, University of Newcastle, New South Wales.

18 New South Wales Parliamentary Papers, vol. 5 (1886), 227-55.

19 Waugh's Australian almanac for the year 1861 (Sydney, 1861); The Australian almanac for the year 1868 (Sydney, 1868); The Australian almanac for the year 1875 (Sydney, 1875); Moore's Australian almanac and handbook for 1880 (Sydney, 1880); Moore's almanac, 1884-6 (Sydney, 1886).

20 Glenda Strachan, 'Caught in the community: teachers' lives in rural schools 1880-1900', in Phil Griffiths and Rosemary Webb eds., Work - organisation - struggle: papers from the seventh National Labour History Conference held at the Australian National University, Canberra, April 19-21, 2001, Australian Society for the Study of Labour History (Canberra, 2001), 347-51; Department of Education, School Files, NSW Archives, Western Sydney Records Centre, Kingswood, New South Wales.

21 For example, Dorothy Baker, The Marsh family tree 1794-1982, typescript (1982), available in the Mitchell Library, Sydney.

22 See www.records.nsw.gov.au/archives/deceased_estate_files_4667.asp.

23 For example, David Adams ed., The letters of Rachel Henning (Ringwood, Victoria, 1969).

24 Death certificates recorded the date and place of death, cause of death, duration of last illness and whether attended by a doctor, parents of the deceased, informant, when and where buried and the presiding clergy, birthplace, marriage(s), children born of all marriages (sometimes omitting deceased children).

25 Glenda Strachan, 'Settling the wet frontier: the Upper Williams Valley, 1850-1880', paper presented at the Australian Historical Association Conference, Hobart, October 1999.

26 Katrina Alford, Production or reproduction? An economic history of women in Australia, 1788-1850 (Melbourne, 1984), 160-1 and 174-6.

27 Australian Bureau of Statistics, Australian Historical Population Statistics, catalogue no. 3105.0.65.001 (2006), Table 6, available at http://www.abs.gov.au/AUSSTATS/ abs@.nsf/DetailsPage/3105.0.65.0012006?OpenDocument.

28 L. T. Ruzicka and J. L. Caldwell, The end of the demographic transition in Australia (Canberra, 1977), 34.

29 Ibid., 34.

30 New South Wales Government Statistician's Office, The Statistician's report on the eleventh census of New South Wales (Sydney, 1894).

31 Norma Townsend, Valley of the Crooked River: European settlement on the Nambucca (Sydney, 1993); Warwick Frost, 'Farmers, government and the environment: the settlement of Australia's wet frontier, 1870-1920', Australian Economic History Review 377, 1 (March 1997), 19-38.

32 Violet Moore, So the sun shines (Taree, 1989), 39-40.

33 Registrar General of New South Wales, Statistical register of New South Wales, printed in New South Wales Legislative Assembly votes and proceedings annually from 1861. 
34 Barry Reay, Microhistories (Cambridge, 1997), chapter 1; Townsend, Valley, 81-8.

35 Glenda Strachan, Ellen Jordan and Hilary Carey, 'Susannah and Elizabeth: the contributions of women to the resources of the Hunter region', in Cynthia Hunter ed., Riverchange (Newcastle, 1998), 115-47.

36 New South Wales Parliamentary Papers, vol. 5 (1886), 227-55; John Fisher, 'Land, labour and co-operation in the Williams Valley, New South Wales in the late Nineteenth Century,' unpublished manuscript (n.d.) in the possession of the authors, 1-4.

37 H. O. Lancaster, 'The causes of the declines in death rates in Australia', Medical Journal of Australia 9 (1967), 937-41.

38 Glenda Strachan and Lindy Henderson, 'Deaths in a rural community: Dungog and the Upper Williams Valley 1856-1910', in Bowden and Kellett eds., Transforming labour, 295-302.

39 Strachan and Henderson, 'Deaths in a rural community'.

40 Dribe, Lundh and Nystedt, 'Widowhood strategies'.

41 New South Wales Legislative Assembly votes and proceedings, vol. V (1886), Appendix 2.

42 Alfred Yewen, Yewen's directory of the landholders of New South Wales (Sydney, 1900).

43 New South Wales Legislative Assembly votes and proceedings; Yewen's directory.

44 New South Wales Civil Registration Certificates of Births, Deaths and Marriages (see note 17 above).

45 Pine Brush is situated about equidistant from Dungog and Clarence Town. The birth of some of the children and Vincent's death were registered at Clarence Town. The New South Wales online historical index of births, deaths and marriages has supplemented the more detailed records obtained for the Dungog district; see www.bdm.nsw.gov.au/ familyHistory/search.htm.

46 The census identified 'head of household' on the date of the census, and this was usually the husband and father. However, if he was absent for any reason, the wife and mother was usually designated 'head of household' for census purposes.

47 Dungog Chronicle, 21 April 1891.

48 Maitland Mercury, 16 January 1872.

49 Waugh's Australian almanac for the year 1861; The Australian almanac for the year 1868; Australian almanac for the year 1875; Moore's Australian almanac and handbook for 1880; Moore's almanac, 1884-6.

50 In 1879 Henry, aged 26, married Mary Ann. He erected new premises and expanded the store, dying in 1901 at the age of 48 (Dungog Chronicle, 24 September 1901).

51 Ibid., 25 October 1896.

52 Ibid., 7 June 1896; see the illustration of the house in Newcastle Herald, 27 July 2002.

53 New South Wales online historical index of births, deaths and marriages; see note 45 above.

54 Glenda Strachan, 'The reproduction of labour power: the work of midwives and "handywomen" in rural New South Wales, 1850-1880', in Robert Hood and Ray Markey eds., Labour and community: proceedings of the sixth National Conference of the Australian Society for the Study of Labour History, 1999 (Wollongong, 1999), 170-5.

55 The Civil Registrations and Anglican Church parish registers are both used in this research: the civil marriage certificate in use for most of this period lacks the necessary information as the wrong form was gazetted.

56 Details from Civil Registration Certificates of Marriages, Dungog District, 1856-1910, and Anglican parish registers, 1854-1894.

57 New South Wales Civil Registration Certificates of Deaths; see also Glenda Strachan, "Present at the birth: midwives, "handywomen" and neighbours in rural New South Wales, 1850-1900', Labour History 81 (2001), 24. 
58 New South Wales online historical index of births, deaths and marriages; see note 45 above. Names may be illegible in the original certificates and some individuals with names that occur commonly cannot be identified with certainty.

59 Strachan, 'Settling the wet frontier', 6 .

60 Strachan, 'The reproduction of labour power', 173.

61 Moore, So the sun shines, 39-40.

62 Old Age Pension Act (NSW), 1900. There were strict means and behavioural conditions.

63 Strachan and Henderson, 'Lost labourers'.

64 Strachan, Jordan and Carey, 'Susannah and Elizabeth'.

65 A. W. McMinn, 'James Murray 1928-1909', Australian dictionary of biography, vol. 5 (Melbourne, 1974), 320-1; Stephen Garton, 'Out of luck' : poor Australians and social welfare 1788-1988 (Sydney, 1990), 50; John Ramsland, Children of the backlanes: destitute and neglected children in colonial New South Wales (Sydney, 1986), 139.

66 Dungog Chronicle, 2 August 1898.

67 New South Wales online historical index of births, deaths and marriages; see note 45 above.

68 Wall, 'Elderly widows and widowers'.

69 Townsend, Valley of the Crooked River, 148-9; Moore, So the sun shines. 